\title{
FOXP2 and language alterations in psychiatric pathology
}

\author{
Xochitl Helga Castro Martínez,' María Dolores Moltó Ruiz, 2,3 Mirna Edith Morales Marin, \\ Julio César Flores Lázaro, ${ }^{4}$ Javier González Fernández, ${ }^{2}$ Nora Andrea Gutiérrez Najera, \\ Daniel Eduardo Alvarez Amado, ${ }^{5}$ José Humberto Nicolini Sánchez
}

Laboratorio de Genómica de Enfer medades Psiquiátricas y Neurodegenerativas, Instituto Nacional de Medicina Genómica, Ciudad de México, México.

2 Departamento de Genética. Universitat de València. España.

${ }^{3}$ INCLIVA. CIBERSAM, España

${ }^{4}$ Hospital Psiquiátrico Infantil Dr. Juan N. Navarro, Secretaría de Salud, México.

5 Departamento de Neurología, Hospital Infantil de México Fede rico Gómez, Ciudad de México, México

Correspondence:

José Humberto Nicolini Sánchez Laboratorio de Genómica de Enfermedades Psiquiátricas y

Neurodegenerativas, Instituto

Nacional de Medicina Genómica.

Periférico Sur 4809, Arenal Tepepan,

Tlalpan, 14610, Ciudad de México,

México

Phone: +52 (55) 5350 - 1900 ext.

1196

Email: hnicolini@inmegen.gob.mx

Received: 27 August 2019

Accepted: 14 November 2019

Citation:

Castro Martínez, X. H., Moltó Ruiz, M. D. Morales Marin M. E. Flores Lázaro, J. C., González Fernández, J., Gutiérrez Najera, N. A., Alvarez Amado, D. E., \& Nicolini Sánchez, 1. H. (2019). FOXP2 and language alterations in psychiatric pathology. Salud Mental, 42(6), 297-308.

DOI: $10.17711 /$ SM.0185-3325.2019.039

\begin{abstract}
Background. From the first reports of the linguist Noam Chomsky it has become clear that the development of language has an important genetic component. Several reports in families have shown the relationship between language disorders and genetic polymorphisms. The FOXP2 gene has been a fundamental piece for the understanding of language development. This gene codes for a transcription factor containing a forkhead domain of DNA binding and participates in the regulation of the expression of a large number of genes involved in the embryonic development of fundamental neuronal structures needed for the development of speech and language. Objective. To present an updated view of the relationship between FOXP2 and language alterations in psychiatric pathology. Method. Narrative review of information reported in databases on the recent advances supporting genetic participation in language disorders of psychiatric illness. Results. Update of content related to FOXP2 and its participation in language alterations in psychiatric diseases. Discussion and conclusion. Advances in the genetic study of language disorders in psychiatric pathology open up new avenues of investigation that allow us to explore how language emerged and how it evolved, as well as to carry out comparative studies on the structure and functioning of genes to approach the understanding of this complex characteristic that makes us human
\end{abstract}

Keywords: FOXP2, language alterations, psychiatric pathology.

\section{RESUMEN}

Antecedentes. Desde los primeros reportes del lingüista Noam Chomsky ha quedado claro que el desarrollo del lenguaje tiene un importante componente genético. Diversos reportes en familias han mostrado la relación entre los trastornos del lenguaje y ciertos marcadores genéticos. El gen FOXP2 ha sido una pieza fundamental para entender el desarrollo del lenguaje. Se trata de un gen que codifica para un factor de transcripción con un dominio forkhead de unión al DNA y que participa en la regulación de la expresión de un gran número de genes durante el desarrollo embrionario de estructuras neuronales fundamentales para el desarrollo del habla y el lenguaje. Objetivo. Presentar un panorama actualizado de la relación del gen FOXP2 en las alteraciones del lenguaje en la patología psiquiátrica. Método. Revisión narrativa de la información reportada en diversas bases de datos sobre los recientes avances que soportan la participación genética en las alteraciones del lenguaje presentes en enfermedades psiquiátricas. Resultados. Actualización del contenido relacionado con el gen FOXP2 y su participación en las alteraciones del lenguaje en las enfermedades psiquiátricas. Discusión y conclusión. Los avances en el estudio genético de las alteraciones del lenguaje en la patología psiquiátrica abren nuevos caminos de investigación que permiten explorar cómo surgió y cómo ha evolucionado el lenguaje, así como para llevar a cabo estudios comparativos sobre la estructura y el funcionamiento de genes para aproximarse al entendimiento de esta compleja característica que nos hace humanos.

Palabras clave: FOXP2, alteraciones del lenguaje, patología psiquiátrica 


\section{BACKGROUND}

\section{Importance of language disorders in psychiatric diseases}

One of the most relevant characteristics of the human species is the ability to communicate through language. This skill is acquired by imitation in the first years of life. Impairment in the learning process to communicate is observed during child development, around five years old. These processes are crucial for the optimal development of social relationships.

There is limited information about the prevalence of language disorders. Epidemiologic studies have estimated the rate of speech and language impairments among populations. According to data from the XII Censo General de Población y Vivienda en México 2000 (Instituto Nacional de Estadística, Geografía e Informática [INEGI] 2000), the prevalence of language problems fluctuates between $4.7 \%$ and $14.2 \%$ across the country (Instituto Nacional de Estadística, Geografía e Informática [INEGI], 2004). Since language impairment detection involves early stages of childhood, it has been estimated a prevalence of $2-3 \%$ for language disorders and 3-6\% for speech disorders in school children without signs of neurological or genetic alterations. However, this prevalence reaches $15 \%$ in preschool age. Language problems are more frequent in boys than girls and in individuals who have a family history with language or speech delays and reading problems (Moreno-Flagge, 2013; Barragán \& Lozano, 2011). Language and communication difficulties can be attributed to several causes, ranging from a physical disability to a learning difficulty, often due to deficits in cognitive functioning (Chan \& Fugard, 2018).

A wide range of neuropsychiatric disorders has been reported in children from preschool to school ages, and in some cases continues into adolescence and adulthood (Chan \& Fugard, 2018). In addition of symptoms in first episodes of mental disorders, other conditions frequently co-occur, such as anxiety, conduct, and learning disorders, but more importantly for this review, speech, language, and communication difficulties (SLCDs), which are among the most common (Chan \& Fugard, 2018).

It has been reported that SLCD goes undetected in the clinical practice of psychiatric diseases. However, $70 \%$ of children referred to psychiatric services have shown a diagnosis of language impairment (Cohen, Davine, Horodezky, Lipsett, \& Isaacson, 1993; Giddan, Milling, \& Campbell, 1996). Two major and frequent mental disorders in humans, autism and schizophrenia, are characterized by language and communication problems in a different age of appearance. Patients with autism show a reduced interest and ability in communication, while in schizophrenia speech is disorganized leading to failure in communication (Wang, Jeffries, \& Wang, 2016).
The attention-deficit hyperactivity disorder (ADHD) is a prevalent childhood neuropsychiatric condition that shows comorbidity with speech, language and communication difficulties. Bruce, Thernlund, and Nettelbladt (2006), reported that about half of children with ADHD were referred to speech and language therapists. Likewise, other authors found that $68 \%$ of children with ADHD had SLCDs (Trautman, Giddan, \& Jurs, 1990).

Some clinical studies have reported the presentation of specific language impairment (SLI) in patients with bipolar disorder, suggesting that deficiencies in verbal functions are among the most outstanding. For example, interpretation, writing, and oral comprehension are presented as being below the expected considering the age and intellectual coefficient (Mattos, Rabelo, Gueiros, Soares, \& Coutinho, 2009). Alterations in verbal fluency, both formal and semantic fluency, have also been reported in patients with bipolar disorder (Radanovic, Nunes, Gattaz, \& Forlenza, 2008).

\section{Brain organization of language}

From the second half of the 19th century, the neural basis of human communication has been centered with the activity of three regions of the left hemisphere: Broca's area in the region of the frontal gyrus (center of the representation of the movements), Wernicke's area in the temporal gyrus (center of the images of the words), and the insula (center of speech) (Fisher \& Marcus, 2006; Ardila, Bernal, \& Rosselli, 2016). These areas represent the key-language specific substrates.

Neuroimaging techniques as positron emission tomography (PET) and functional magnetic resonance imaging (fMRI) have greatly contributed to the advancement in the understanding of the cerebral organization of language (Ardila et al., 2016). Using these techniques, it has been possible to locate the areas of language processing in the brain: language-comprehensive area in the temporal lobe (BA22, BA21) and language production area in the frontal lobe (BA44, BA45) (Ardila et al., 2016). Likewise, different language disorders have been observed according to the specific location of the damage in these areas. Injuries involving the lexical/semantic system (Wernicke's aphasia) and the grammatical system (Broca's aphasia) allow the development of interpretative models of language evolution (Lieberman, 2015). The presence of these neural networks is considered a crucial evolutionary advantage for the unique faculty of language in humans (Friederici \& Chomsky, 2017).

\section{The motor approach to language development}

It has been widely reported that children with SLI also perform more poorly in fine and gross motor abilities than their normative peers (Iverson \& Braddock, 2011). In recent years, a novel proposal for language learning and development has been proposed: the embodied cognition theory (Schoemers 
\& Pulvermüller, 2016). Infants experience an accelerated neuromotor development with better movement's capacities each month in crawling, walking, running, climbing, hugging, etc. According to this theory, these sensorial and motor experiences may represent one of the brain platforms for language learning when the children learn to identify and produce the words that describe these actions. The brain networks that support the execution of these actions also support the comprehension and production of this type of words (Kemmerer \& Gonzalez-Castillo, 2010).

An important aspect in this field is the presence of abundant hand-arm and body gestures in children's oral language communication. This duality (oral language/gestures) is considered part of a complex form of semantic communication. Accordingly, more than half of children with SLI also present clinical performance on gesture imitation tasks (Iverson \& Braddock, 2011). Recently, Trevisan, Sedeño, Birba, Ibáñez, and García (2017) studied the effect of body actions training in the reading performance of narrative events (naturalistic texts) in children with dyslexia. They found that this type of body actions has a significant effect on reading performance. The same effect has also been found in normative studies in adults with hockey-type actions (Beilock, Lyons, Mattarella-Micke, Nusbaum, \& Small., 2008). Recent reviews have confirmed the effect of motor experience on linguistic and cognitive comprehension (Schomers \& Pulvermüller, 2016; Yang, 2014).

Most language expressions in infant and younger children describe body actions (walking, running, climbing, kissing), or specific actions (drinking, playing). All these actions are marked by a verb; verbs selection and use (grammar and semantics) are highly dependent on prefrontal cortex. Particularly, motor and actions verbs are highly dependent on premotor cortex-basal ganglia activation (Andres, Finocchiaro, Buiatti, \& Piazza, 2015). During verb fluency testing, Broca's area activation in children is not as specific and localized as in young adults; progressive parcelling is achieved in Brocas's area as age increases (Holland et al., 2001). These findings indicate a prolonged period of language development. Weakness in verb-argument structures (grammatical simplicity) has been described in children with SLI (Thordardottir \& Weismer, 2002).

Neuroimaging studies in children with language learning difficulties have found that subcortical structures like the basal ganglia show diminished volume compared to normative children, additional to the cortical compromise in development (Krishnan, Watkins, \& Bishop, 2016). Studies of SLI children, including non-affected siblings, reported that the basal ganglia were also compromised (reduced white matter) compared to control children (Badcock, Bishop, Hardiman, Barry, \& Watkins, 2012).

Frequent neuroimaging findings in children with ADHD are alterations in gray or white matter at premotor, motor cortex, and cortico-striate components, mainly basal ganglia (Sutcubasi Kaya et al., 2018). Alterations of the striatal connectivity contribute to deficits in motor and inhibitory control (Barber et al., 2019). The embodied cognition theory may explain some of the language difficulties that are also frequent in children with ADHD. In fact, the prevalence of language difficulties in pediatric ADHD is higher than in normative population (Sciberras et al., 2014). In addition, ADHD children present alterations in fine motor coordination (Fenollar-Cortés, Gallego-Martinez, \& Fuentes, 2017). Very recently, Barber et al. (2019) examined striatal maturation in a cross-sectional sample of 926 participants of the general population, spanning 8 to 22 years of age. The authors hypothesized that developing striatal connections would be predictive of clinical symptom domains (ADHD severity, psychosis, depression, and general psychopathology) in the general population.

The sensorial and motor support of early language development, specifically the cortico-striatal circuits that support naturalistic actions and motor actions, may represent an important pathway to genomic studies on language learning and development.

\section{Genetics of language disorders}

The process of speech and language acquisition is extraordinarily complex because it is one of the most distinguished cognitive developments in human evolution. With adequate opportunity, the vast majority of children rapidly develop efficient spoken language skills during the first few years of life. Sometimes children fail to acquire normal language, and this could be due to a secondary result of physical or neurological problems such as mental retardation, deafness, or cleft-lip or cleft palate defects (Fisher \& Scharff, 2009). However, significant speech and/or language difficulties present in a subset of children remain unexplained (Bishop, 2003) and are heritable disorders. These cases represent a useful way to identify genes involved in the biological bases of human spoken language.

The first direct evidence of a specific gene that influences speech and language acquisition comes from an unusual autosomal dominant form of communication disorder in a large three-generation family, the KE family, a British family named in this way to maintain their anonymity (Lai, Fisher, Hurst, Vargha-Khadem, \& Monaco, 2001). Approximately half the members of this family were affected by a severe speech and language disorder characterized by problems in the mount movements needed for speech (childhood apraxia of speech, also known as developmental verbal dyspraxia), together with impairment in receptive and expressive language (Vargha-Khadem, Watkins, Alcock, Fletcher, \& Passingham, 1995; Watkins et al., 2002; Becker, Devanna, Fisher, \& Vernes, 2018). Linkage studies in the KE family and mapping the translocation breakpoints in an unrelated child with similar language problems (Lai et al., 2000), guided the iso- 
lation of the Forkhead box protein P2 gene (FOXP2). All affected $\mathrm{KE}$ members were heterozygous for a point mutation in this gene, resulting in an amino-acid substitution in the encoded protein (Lai et al., 2001). As indicated in the next section, FOXP2 is a regulatory gene affecting the expression of a high number of downstream target genes.

Since these findings, other genes have been implicated in disorders of speech and language abilities (Table 1) and most of them are targets or interact with FOXP2 as indicated later. Pathogenic mutations in CHD3, SETD1A, WDR5, SETBP1, KAT6A, TNRC6B, and ZFHX4 genes have recently been identified by analyzing whole-genome sequences from nineteen unrelated individuals diagnosed with childhood apraxia of speech (Eising et al., 2019). Interestingly, these genes were highly co-expressed in the developing human brain. The axon guidance receptor gene $R O B O 1$ was described as a risk candidate gene for dyslexia by mapping translocation breakpoints in a dyslexic patient and analyzing its expression in a large pedigree in which dyslexia was linked to the candidate chromosomal region (Hannula-Jouppi et al., 2005). Association studies in linkage regions determined KIAA0319 and DCDC2 as potential risk genes for dyslexia (Cope et al., 2005; Meng et al., 2005) and CMIP and ATP2C2 for SLI (Newbury et al., 2009) GNPTAB, GNPTG, and NAGPA show variants that have been associated with non-syndromic stuttering (Raza et al., 2016). Moreover, several polymorphisms in CNTNAP2 were associated with variations in language-related phenotypes that span different disorders, such as autism, and the general population (Anney, 2013; Newbury et al., 2011; Whitehouse, Bishop, Ang, Pennell, \& Fisher, 2011).

As for other human traits, most cases of developmental speech and language disorders have complex multifactorial inheritance, resulting from multiple risk factors of modest effect size (Graham \& Fisher, 2015). Therefore, the identification of novel genes associated with these disorders is still a challenge. Advances in next-generation sequencing technologies as well as gene expression studies of developing brain could show new neurogenetic pathways implicated in language development.

\section{FOXP2 AND LANGUAGE IMPAIRMENT IN PSYCHIATRIC DISEASES}

\section{FOXP2 function}

The family of transcription factors Forkhead box (Fox) was named after characterizing in the fork head gene $(f k h)$

Table 1

Phenotypes in relation to language and its genetic association

\begin{tabular}{|c|c|c|c|c|}
\hline Phenotype & Clinical observations & Gene & Chromosome & Protein name \\
\hline $\begin{array}{l}\text { Childhood } \\
\text { apraxia } \\
\text { of speech }\end{array}$ & $\begin{array}{l}\text { A disorder of speech motor programming that af- } \\
\text { fects the production, sequencing, timing, and stress } \\
\text { of sounds, syllables, and words. }\end{array}$ & $\begin{array}{l}\text { FOXP2 } \\
\text { CHD3 } \\
\text { SETD1A } \\
\text { WDR5 } \\
\text { SETBP1 } \\
\text { KAT6A } \\
\text { TNRC6B } \\
\text { ZFHX4 }\end{array}$ & $\begin{array}{l}7 q 31.1 \\
7 p 13.1 \\
16 p 11.2 \\
9 q 34.2 \\
18 q 12.3 \\
8 p 11.21 \\
22 q 13.1 \\
8 q 21.13\end{array}$ & $\begin{array}{l}\text { Forkhead box protein P2 } \\
\text { Chromo domain helicase DNA binding protein } 3 \\
\text { SET domain-containing protein } 1 \mathrm{~A} \\
\text { WD repeat domain } 5 \\
\text { SET binding protein } 1 \\
\text { Lysine Acetyltransferase } 6 \mathrm{~A} \\
\text { Trinucleotide Repeat Containing } 6 \mathrm{~B} \\
\text { Zinc Finger Homeobox } 4\end{array}$ \\
\hline $\begin{array}{l}\text { Developmental } \\
\text { dyslexia }\end{array}$ & $\begin{array}{l}\text { Difficulty in learning to read despite conventional } \\
\text { instruction, adequate intelligence, and sociocultural } \\
\text { opportunity: Prevalence from } 5 \text { to } 12 \% \text { of school- } \\
\text { age children even though difficulties persist into } \\
\text { adulthood. }\end{array}$ & $\begin{array}{l}\text { ROBO1 } \\
\text { KIAA0319 } \\
\text { DCDC2 } \\
\text { DNAAF4 }\end{array}$ & $\begin{array}{l}3 p 12.3 \\
6 p 22.3 \\
6 p 22.3 \\
15 q 21.3\end{array}$ & $\begin{array}{l}\text { Roundabout homolog } 1 \\
\text { Dyslexia-associated protein KIAA0319 } \\
\text { Doublecortin domain-containing protein } 2 \\
\text { Dynein axonemal assembly factor } 4\end{array}$ \\
\hline $\begin{array}{l}\text { Specific } \\
\text { language } \\
\text { impairment }\end{array}$ & $\begin{array}{l}\text { It is characterized by difficulty in language acquisi- } \\
\text { tion despite otherwise normal development and in } \\
\text { the absence of any obvious explanatory factors. It } \\
\text { affects } 5 \text { to } 8 \% \text { of preschool children and is highly } \\
\text { heritable but multifactorial. }\end{array}$ & $\begin{array}{l}\text { CNTNAP2 } \\
\text { CMIP } \\
\text { ATP2C2 }\end{array}$ & $\begin{array}{l}7 q 35 \\
16 q 23.2 \\
16 q 24.1\end{array}$ & $\begin{array}{l}\text { Contactin-associated protein-like } 2 \\
\text { C-Maf-inducing protein } \\
\text { Calcium-transporting ATPase type 2C member } 2\end{array}$ \\
\hline Stuttering & $\begin{array}{l}\text { Disorder of the speech flow characterized by in- } \\
\text { voluntary repetitions or prolongations of sounds or } \\
\text { syllables, and by interruptions of speech known as } \\
\text { blocks. } \\
\text { It typically arises in young children, affecting at least } \\
15 \% \text { in an age range from } 4 \text { to } 6 \text { years. The disor- } \\
\text { der usually resolves spontaneously before adoles- } \\
\text { cence, leading to a population prevalence of } 1 \text { to } \\
2 \% \text { among adults. }\end{array}$ & $\begin{array}{l}\text { GNPTAB } \\
\text { AP4E1 } \\
\text { GNPTG } \\
\text { NAGPA }\end{array}$ & $\begin{array}{l}12 q 23.2 \\
15 q 21.2 \\
16 p 13.3 \\
16 p 13.3\end{array}$ & $\begin{array}{l}\text { N-Acetylglucosamine-1-phosphotransferase subunits } \alpha / \beta \\
\text { Adaptor related protein complex } 4 \text { subunit } \varepsilon 1 \\
\mathrm{~N} \text {-Acetylglucosamine-1-phosphotransferase subunit } Y \\
\mathrm{~N}-\text { Acetylglucosamine-1-phosphodiester Alpha-N-Ace-tyl- } \\
\text { glucosaminidase }\end{array}$ \\
\hline
\end{tabular}

Reviewed in National Center for Biotechnology Information (s.f.) 
of Drosophila melanogaster mutations causing defects in head fold involution during embryogenesis resulting in spiked head in adult flies (Weigel, Jürgens, Küttner, Seifert, \& Jäckle, 1989). Hundreds of Fox genes have been identified and classified into 19 subfamilies based on the evolutionary divergence of their forkhead DNA binding domain (FHD) (Hannenhalli \& Kaestner, 2009; Morris, Stoychev, Naicker, Dirr, \& Fanucchi, 2018). One of them is the
FOXP subfamily, characterized by being comprised of four members (FOXP1-4) highly homologous (exhibit 55-65\% sequence identity) and being multidomain proteins, giving them a peculiar molecular structure, containing a conserved DNA-binding forkhead box and functional domains: leucine zipper and zinc finger located N-terminal to the FHD. FOXP1, 2 and 4 contain a polyglutamine tract (Bowers \& Konopka, 2012; Song, Tang, \& Wang, 2016; Morris et al.,

a)

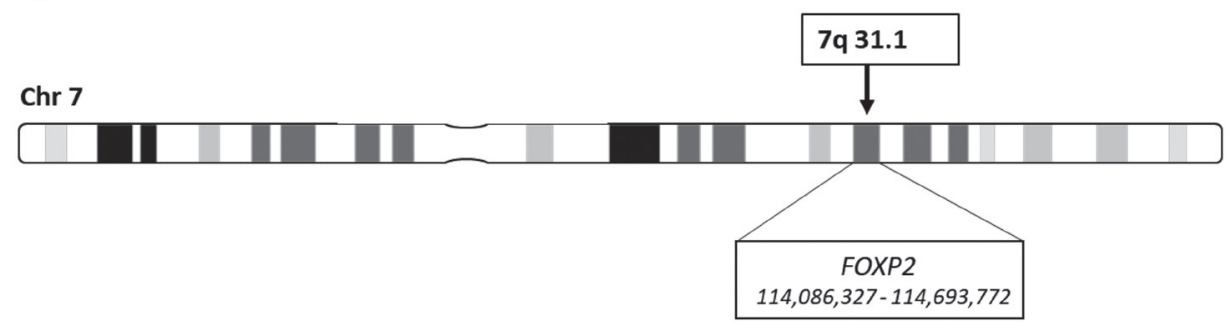

b)

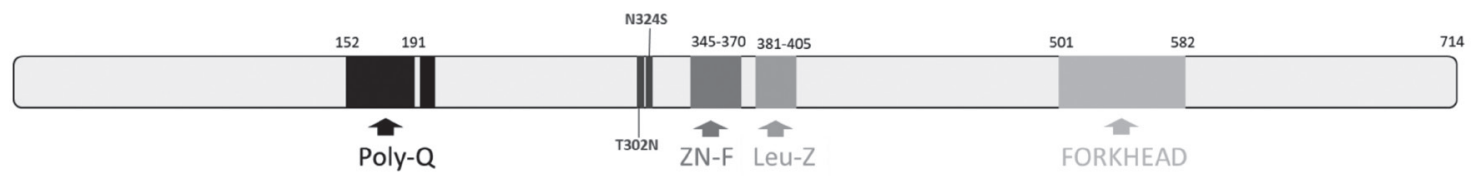

c)

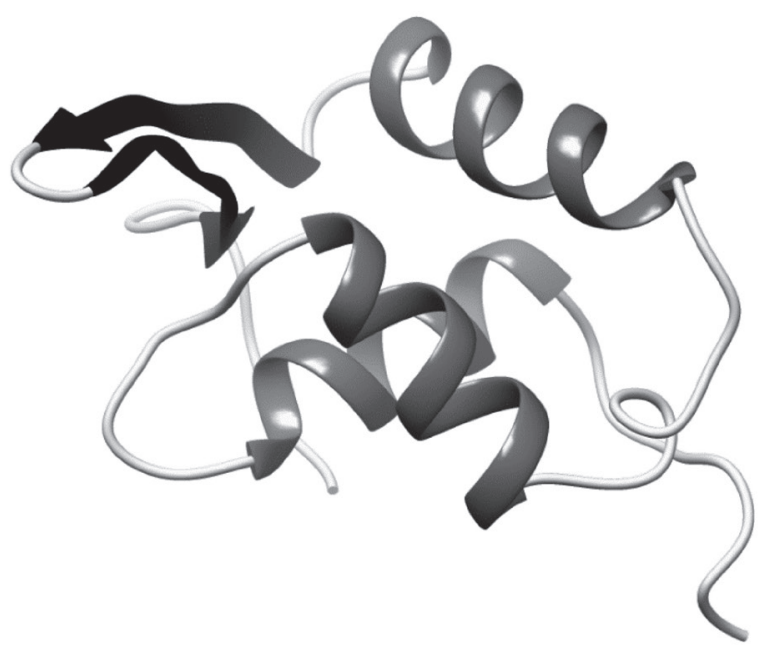

Figure 1. Human FOXP2. a) Chromosome 7 rerpesentation. Black arrow marks $7 \mathrm{q} 31.1$ band and box indicate the position of human FOXP2 gene (NCBI gene ID: 93986). b) Representation of structural and functional domains of human FOXP2 protein (GenBank: AAI43868.1). Poly-Q sequence, $\mathrm{Zn}$ finger, Leucine zipper and Forkhead domain (also known as a "winged helix") are represented from black to light grey respectively. Evolutionary changes in two specific aminoacids between human and chimpanzee (T302N and N324S) are represented. This prediction has been performwed using SMART (Simple Modular Architecture Research Tool) software from EBI (European Bioinformatics Institute). c) 3D structure prediction of the FOXP2 protein using Phyre 2 (Kelley et al., 2015) and Chimera 1.12 software (Pettersen et al., 2004). It presents three $\alpha$-helixes and two $\beta$-sheets. 
2018) (Figure 1). These proteins showed overlapping expression in the developing brain, as well as in other organs. FOXP3 disruption causes an immunological disorder: IPEX syndrome (immunodysregulation polyendocrinopathy enteropathy X-linked,). Mutations in/at FOXP1, FOXP2, and FOXP4 have each been linked to distinct neurodevelopmental disorders, which include global developmental delay an ID (intellectual disability), sometimes accompanied by features of autism and impaired speech and language abilities (McKusick, 1997).

Its participation in the differentiation of the lung epithelium has been demonstrated through its function of transcriptional repressor (National Institutes of Health, The European Molecular Biology Laboratory, \& State Secretariat for Education, Research and Innovation SERI, 2002). It has been shown that this gene orchestrates the expression of other genes by interactions with proteins that act upstream of FOXP2 to control its expression (Nudel \& Newbury, 2013). FOXP2 contains a winged helix DNA binding domain and two subdomains of transcriptional repression in the N-terminal region, which contain various protein-protein interaction motifs, suggesting an interaction with other transcription factors with activator or repressor functions (Nudel \& Newbury, 2013). It has also been reported that FOXP2 interacts synergistically with the co-repressor CtBP-1 to inhibit transcription (Li, Weidenfeld, \& Morrisey, 2004).

Although the role in the activation/repression of genes involved in the neurogenesis or neuronal function remains unknown, it has been reported that FOXP 2 is able to repress certain tissue-specific genes, for example, Li and colleagues classified the Foxp subfamily as potent transcriptional repressors by inhibiting gene expression through their interaction with repressive chromatin remodeling complexes such as NuRD (Li et al., 2016). For its part, Shu and coworkers reported the repressive activity of Foxp2 through its binding to homologous $\mathrm{N}$-terminal repression domain with promoters of lung-enriched genes (Shu, Yang, Zhang, Lu, \& Morrisey, 2001).

The FOXP2 protein is also active from spin cord to organs such as spleen, intestine, skeletal muscle, lungs, and kidney (Shu et al., 2001; Becker et al., 2018; Song et al., 2016), including the fetal and adult brain (National Center for Biotechnology Information, U.S. National Library of Medicine. s.f.; OMIM, s.f.). In humans, high expression has been reported in the process of neuronal specification and brain configuration has been detected from as early as the 44th day of gestation (Lai, Gerrelli, Monaco, Fisher, \& Copp, 2003). The expression of FOXP2 begins to decay postnatally until it becomes undetectable in the adult stage brain (Teramitsu, Kudo, London, Geschwind, \& White, 2004). Unlike its expression in the brains of other vertebrates such as rodent and zebra finch, is found in constant and high expression from the embryonic to the adult stage
(Song et al., 2016; Teramitsu et al., 2004; Ferland, Cherry, Preware, Morrisey, \& Walsh, 2003). FOXP2 expression is first detected in the midline of the hindbrain, and subsequently becomes more complex as the embryonic development progresses. The expression of the FOXP 2 gene in the human brain is limited to areas such as striatum, thalamic nuclei, hippocampus, cerebellum, and cortex, all of them belonging to the cortico-striatal region with great potential for psychiatric disorders and essential for the normal development of speech and language (U.S. Department of Health \& Human Services, s.f.; Song et al., 2016). Some of these brain regions, such as the caudate nucleus, the putamen, and the cerebellum were previously implicated in the neuroimaging studies as regions in which the affected KE family members differed from the unaffected members or controls in terms of structural abnormalities (Bruce \& Margolis, 2002; Watkins et al., 2002).

This gene is required for the proper development of speech and language regions of the brain during embryogenesis, and may be involved in a variety of biological pathways and cascades that may ultimately influence language development. Mutations in this gene cause speech-language disorder 1 (SPCH1), also known as autosomal dominant speech and language disorder with orofacial dyspraxia. Multiple alternative transcripts encoding different isoforms have been identified in this gene $\left(G\right.$ eneCards ${ }^{\circledR}$ : The Human Gene Database, 1997). RT-qPCR and Western blotting indicated differential regulation of 13 new additional target genes in response to overexpression of human FOXP2 (Oswald et al., 2017).

\section{FOXP2 evolution}

The FOXP2 gene was the first to appear in the human capacity scene, named language. This gene has a sequence highly conserved notwithstanding the distance between vertebrate species. Despite this conservation, two aminoacids substitutions occurred on the human branch after splitting from the chimpanzee and absent in all the others primates, indicating a selective sweep that probably occurred within the past 200,000 years. These two nonsynonymous substitutions seem to have been subject to positive selection in recent human history that genetically mediated language (Fisher \& Marcus, 2006). FOXP2 played a key role in the development of modern language, unique to Homo sapiens. Presumably, these aminoacid changes in exon 7 of the FOXP2 gene were selected because they allow to achieve a precise control of the orofacial movements and facilitates the refinement of the articulation of which human language makes use (Enard et al., 2002).

Despite the above, recent findings have shown controversy in the evidence of positive selection of FOXP2 in humans. Atkinson et al. (2018) reported not finding evidence that the two aminoacid substitutions from the FOXP2 
Table 2

Genetic alterations in FOXP2 that cause speech and language disorders

\begin{tabular}{|c|c|c|}
\hline Mutation & $\begin{array}{c}\text { Affected individuals with } \\
\text { FOXP2-related language } \\
\text { disorder (\%)1 }\end{array}$ & Mode of inheritance and recurrence risk ${ }^{1}$ \\
\hline Gene deletion & $\approx 52$ & $\begin{array}{l}\text { About } 80 \% \text { of large contiguous gene deletion } \\
\text { that includes FOXP2 are de novo; the remainder } \\
\text { are inherited in an autosomal dominant pattern. }\end{array}$ \\
\hline $\begin{array}{l}\text { Chromosomal rearrangement (trans- } \\
\text { location, inversion) }\end{array}$ & $\approx 8$ & $\begin{array}{l}\text { Sibs with a parent having a structural variant } \\
\text { affecting chromosome } 7 \text { show increased risk, } \\
\text { which depend on the specific structural variant. }\end{array}$ \\
\hline $\begin{array}{l}\text { Maternal uniparental disomy of chro- } \\
\text { mosome } 7\end{array}$ & $\approx 11$ & $\begin{array}{l}\text { Risk of recurrence is not augmented over that of } \\
\text { the general population. }\end{array}$ \\
\hline $\begin{array}{l}\text { Sequence variant (missense, non- } \\
\text { sense, and splice-site variants and } \\
\text { small intragenic deletions/insertions) }\end{array}$ & $\approx 29$ & $\begin{array}{l}\text { Approximately } 70 \% \text { are de novo; the remainder } \\
\text { are inherited in an autosomal dominant manner. }\end{array}$ \\
\hline
\end{tabular}

${ }^{1}$ Reviewed in Morgan et al., 2017.

gene have been associated with recent positive selection in humans $<200$ kya (thousand years ago). Conversely, they have suggested an ancient selective sweep that could explain the presence of the two derived substitutions in humans (Atkinson et al., 2018).

\section{FOXP2 disruption in language impairment}

Up to now, data indicated that the disruption of one copy of FOXP2 is sufficient to derail speech development, causing a rare form of speech and language impairment. No human has yet been identified with the homozygous loss of FOXP2 function. Mice completely lack with functional Foxp2 (the murine orthologue) display severe motor impairment, reduced growth, and delayed cerebellar development, dying few weeks after birth. Disruption of one copy of Foxp 2 provokes important alterations in ultrasonic sounds that juveniles produce in response to separation from their mothers (Shu et al., 2005).

Table 2 summarizes the genetic alterations found in FOXP2-related speech and language disorders. Chromosomal rearrangements and deletions disturbing one allele result in decreased FOXP 2 protein level. Missense mutations produce abnormal proteins in which DNA binding activity, dimerization (transcriptional regulation of downstream target genes requires protein dimerization), or nuclear translocation are altered. These mutations result either in haploinsufficiency of FOXP2 or have a dominant-negative effect (Vernes et al., 2006; Estruch, Graham, Chinnappa, Deriziotis, \& Fisher, 2016). The pathogenic variant in the KE family (p.R553H) changes a conserved residue in the DNA Forkhead binding domain, impairing the ability of FOXP2 to bind target sites (Stroud et al., 2006). In addition, the $\mathrm{R} 553 \mathrm{H}$ mutation affects the nuclear localization signal at $\mathrm{C}$-terminus and consequently hampers the nuclear localization of the protein (Mizutani et al., 2007). Maternal uniparental disomy of chromosome 7 has also been reported in several cases, suggesting a differential allelic expression of FOXP2, with a restricted expression of the paternal copy (Feuk et al., 2006). However, there are contradictory results concerning the imprinting status of the FOXP2 locus (Thomas et al., 2012).

Regardless of the mutation in FOXP2, childhood apraxia of speech constitutes a central phenotype of the resulting speech and language disorder. Additional findings include oral motor deficits, global developmental delay, and autism spectrum disorders that are more likely caused by large copy number variants or structural variants affecting FOXP2 (Morgan, Fisher, Scheffer, \& Hildebrand, 2017). Among all cases of childhood apraxia of speech, which have a highly heterogeneous genetic basis, what fraction is caused by mutation in FOXP2 is not yet well established.

\section{FOXP2 targets}

The identification of novel genes associated with language disorders is a difficult process because their effect in this complex condition is low. Nowadays linkage studies have contributed to identify new genes, and GWAS and big cohorts of patients are the main and most useful tools to stablish genetic associations. As indicated before, FOXP2 has been the most studied and important gene related with human language, mainly by its biological relevance. Thus, the identification of FOXP2 targets related with language constitutes a new way to approach the role of genetics in human language development (Figure 2).

As described in Konopka et al. (2009), CACNB2 (Calcium Voltage-Gated Channel Auxiliary Subunit Beta 2) gene expression is regulated by FOXP2. This gene encodes for a protein that contributes to the function of the calcium channel by increasing peak calcium current and shifting 

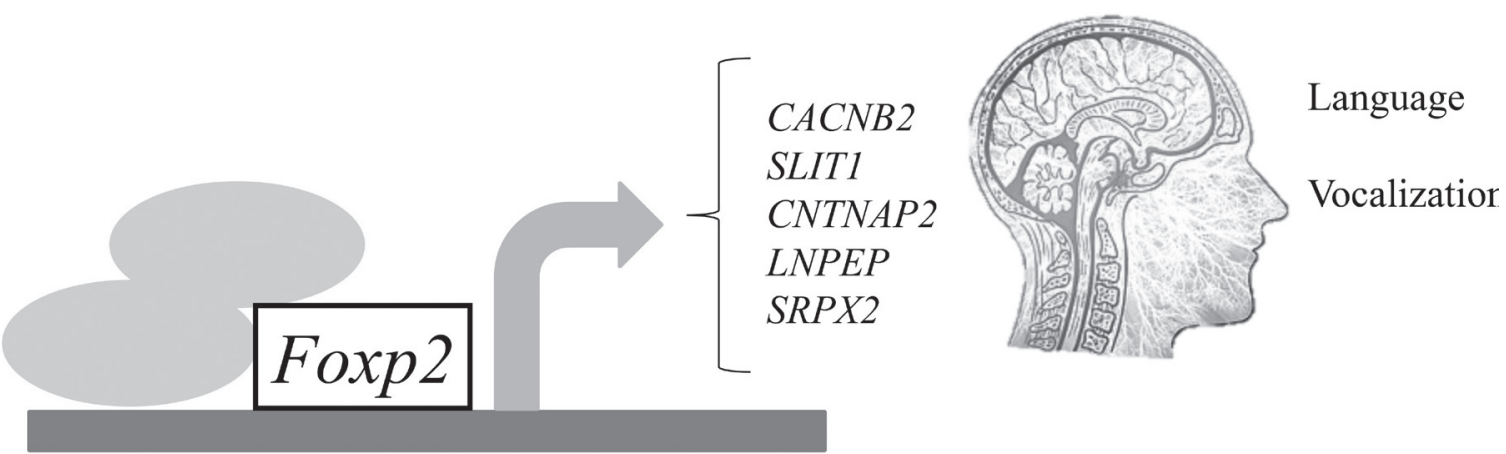

Figure 2. FOXP2 might control vocalization and language development in cooperation with other proteins (grey circles in the figure) such as FOXP1 (Xu et al., 2018), by regulating the expression of target genes (grey arrow) that participates in the formation of language related circuits in the brain.

the voltage dependencies of activation and inactivation. Mutations in $C A C N B 2$ have been associated with Brugada syndrome (Brugada et al., 2005), but also common single nucleotide polymorphisms (SNPs) of CACNB2 have been shown to contribute to a range of neurodevelopmental disorders, including language disorders (Kim \& State, 2014). Chip-microarray techniques have allowed to identify the SLIT1 (Slit Guidance Ligand 1) gene as another FOXP2 target (Spiteri et al., 2007). Along with the SLIT2 protein, SLIT1 is involved in neural axon guidance during neural development, acting as a molecular cue in cellular migration mediated by interaction with ROBO receptors (Plump et al., 2002). This interaction is the foundation of the SLIT-ROBO pathway, which has been related with speech sound language disorders and the evolution of vocal learning (Wang et al., 2015).

As mentioned above, polymorphisms of CNTNAP2 are related with a variety of language phenotypes in different disorders. This gene is down-regulated by FOXP2 (Vernes et al., 2008) and encodes a member of neurexin family required for the radial and longitudinal organization of myelinated axons by its mediation function between neurons and glia during nervous system development (Gao et al., 2019). According to some authors, CNTNAP2 is also linked to language development by its interaction with oxytocin (OXT) during critical developmental windows (Peñagarikano et al., 2015), as OXT would affect brain components closely interwoven to different facets of language (Theofanopoulou, 2016). Gregory et al. (2009) have reported that in patients with autism spectrum disorder, who present language deficits as a central feature of the phenotype, a mechanism of epigenetic misregulation of the OXTR (oxytocin receptor gene) through genetic silencing with DNA methylation associated with the activity and functional coupling of neurons impacting this on language performance (Puglia, Lillard, Morris, \& Connelly, 2015). These studies also associate the LNPEP (Leucyl and Cystinyl Aminopeptidase) gene to language through its func- tion as a peptidase that metabolizes oxytocin. Moreover, $L N P E P$ controls synaptic transmission and formation, and was identified as a FOXP2 target, which regulates LNPEP by repressing its expression (Vernes et al., 2007). In addition, two variants of SRPX2 (Sushi Repeat Containing Protein X-Linked 2) gene (Asn327Ser and Tyr72Ser) have been described as pathogenic, causing rolandic epilepsy and intellectual disability and speech difficulties (Roll et al., 2006). SRPX2 encodes for a protein involved in the development of speech and language centers in the brain, acting as a ligand for the urokinase plasminogen activator surface receptor (uPAR) (Royer-Zemmour et al., 2008). Besides, Roll et al. (2010) showed that there is a transcriptional regulatory network between FOXP2 protein and the SRPX2/uPAR complex, so that FOXP2 regulates the expression of both.

There are more than 100 genes considered as FOXP2 targets (Konopka et al., 2009) but their relationship with language remains unclear. Further investigations are needed to understand the genetics of human language.

\section{FOXP2 and psychiatric diseases}

Shared genetic vulnerability has been identified in different neuropsychiatric disorders (Ivorra et al., 2014). FOXP2 is one of the 23 clinically relevant genes shared by autism spectrum disorder (ASD), schizophrenia, and bipolar disorder (Khanzada, Butler, \& Manzardo, 2017). This gene was considered as a potential susceptibility locus in neuropsychiatric disorders in which language impairment may occur, such as autism and schizophrenia. In the first condition, deficits in social communication are a key phenotype appearing in early childhood. In schizophrenia, language problems are characterized by disorganized speech and debut in young adulthood. Both conditions show complex etiology, with a genetic component as a central factor associated with environmental triggers that together may affect brain development. 
Large chromosomal deletions involving the FOXP2 locus have been described in patients suffering both ASD and developmental verbal dyspraxia (Feuk et al., 2006). It has been proposed that genes regulated by FOXP2, such as the neurexin gene CNTNAP2, are involved in both language impairment and autism. Neuroimaging and genetic data support that CNTNAP2 is a risk factor for ASD and related neurodevelopmental disorders (Peñagarikano \& Geschwind, 2012). Very recently, Zhou et al. (2019) reported rare functional variants of this gene when resequencing 358 ASD candidate genes in a case-control cohort from Chinese population. CNTNAP2 is proposed to play a role in controlling the assembly of functional network between important integrative connectivity hubs of the mammalian brain, thereby disruption of the gene function might predispose to autism and other neurodevelopmental disorders by specific alterations of connectivity in prefrontal areas (Liska et al., 2017).

$F O X P 1$, a paralog of FOXP2, is considered a high-confidence causal ASD gene. Several studies have reported different mutations in FOXP1 related to the presence of ASD traits, intellectual disability, and psychiatric and language features (Meerschaut et al., 2017). Dimerization of FOXP proteins (homo- and hetero-dimerization) occurs for transcriptional regulation of target genes (Li et al., 2004). Interestingly, Foxp1 and Foxp2 of zebra finch, alone or in combination, can differentially control the CNTNAP2 promoter (Mendoza \& Scharff, 2017). These results show how versatile the regulation of these proteins can be in respect to the transcriptional activity of the target genes and add complexity in their role in the development of neurodevelopmental disorders.

FOXP2 was first related with schizophrenia in a case-control study in which a FOXP2 polymorphism, rs2396753, was associated with thought disorders and auditory hallucinations in patients with schizophrenia (Sanjuán et al., 2006). This polymorphic variant was later correlated with grey matter reduction in patients with this disease (Španiel et al., 2011). Interestingly, rs2396753 was also linked to activity in brain areas related to language in healthy adults (Ocklenburg et al., 2013). Collectively, these data suggested that FOXP2 polymorphisms might play a neurogenic role in language impairment in schizophrenia. However, it remains controversial whether common FOXP2 polymorphisms could affect brain structures and play a major role in language and speech impairment in schizophrenia (Hoogman et al., 2014; McCarthy, Clark, Jablensky, \& Badcock, 2019). In addition, the analysis of multiple classes of genetic variation in large genomic datasets concluded that CNTNAP2 may not be a robust risk gene for psychiatric phenotypes (Toma et al., 2018). The effect of the polymorphisms of FOXP2, and its target genes like $C N T N A P 2$, in language dysfunction of neuropsychiatric disorders remains to be clarified.

\section{DISCUSSION AND CONCLUSION}

Advances in the molecular study of psychiatric diseases have brought along findings that have allowed to unravel the clinical complexity that comprises them. However, in the same way they have been the gateway of a network interrelated mechanisms between the clinic they present.

The equation FOXP2-language impairment-psychiatric illness is still an interesting route to study the large percentage of patients with psychiatric diseases who continue to present some alteration of language within the clinical core.

\section{Funding}

None.

\section{Conflicts of interest}

The authors declare they have no conflicts of interest.

\section{REFERENCES}

Andres, M., Finocchiaro, C., Buiatti, M., \& Piazza, M. (2015). Contribution of motor representations to action verb processing. Cognition, 134, 174-184. doi: 10.1016/j.cognition.2014.10.004

Anney, R. J. L. (2013). Chapter 2.3 Common genetic variants in autism spectrum disorders. In The Neuroscience of Autism Spectrum Disorders (pp. 155-167). doi: 10.1016/b978-0-12-391924-3.00010-7

Ardila, A., Bernal, B., \& Rosselli, M. (2016). How localized are language brain areas? A review of brodmann areas involvement in oral language. Archives of Clinical Neuropsychology, 31(1), 112-122. doi: 10.1093/arclin/acv081

Atkinson, E. G., Audesse, A. J., Palacios, J. A., Bobo, D. M., Webb, A. E., Ramachandran, S., \& Henn, B. M. (2018). No evidence for recent selection at FOXP2 among diverse human populations. Cell, 174(6), 1424-1435. doi: 10.1016/j.cell.2018.06.048

Badcock, N. A., Bishop, D. V., Hardiman, M. J., Barry, J. G., \& Watkins, K. E. (2012). Co-localisation of abnormal brain structure and function in specific language impairment. Brain and Language, 120(3), 310-320. doi: 10.1016/j. band1.2011.10.006

Barber, A. D., Sarpal, D. K., John, M., Fales, C. L., Mostofsky, S. H., Malhotra, A. K., ... Lencz, T. (2019). Age-normative pathways of striatal connectivity related to clinical symptoms in the general population. Biological Psychiatry, 85(11), 966-976. doi: 10.1016/j.biopsych.2019.01.024

Barragán, P. E., \& Lozano, S. S. (2011). Identificación temprana de trastornos del lenguaje. Revista Médica Clínica Las Condes, 22(2), 227-232. doi: 10.1016/ s0716-8640(11)70417-5

Becker, M., Devanna, P., Fisher, S. E., \& Vernes, S. C. (2018). Mapping of human FOXP2 enhancers reveals complex regulation. Frontiers in Molecular Neuroscience, 11, 47. doi: 10.3389/fnmol.2018.00047

Beilock, S. L., Lyons, I. M., Mattarella-Micke, A., Nusbaum, H. C., \& Small, S. L. (2008). Sports experience changes the neural processing of action language. Proceedings of the National Academy of Sciences, 105(36), 13269-13273. doi: 10.1073/pnas.0803424105

Bishop, D. V. (2003). Genetic and environmental risks for specific language impairment in children. International Journal of Pediatric Otorhinolaryngology, 67(Suppl 1), S143-S157. doi: 10.1016/j.ijporl.2003.08.014

Bowers, J. M., \& Konopka, G. (2012). The role of the FOXP family of transcription factors in ASD. Disease Markers, 33(5), 251-260. doi: 10.3233/DMA-20120919

Bruce, B., Thernlund, G., \& Nettelbladt, U. (2006). ADHD and language impairment. European Child \& Adolescent Psychiatry, 15(1), 52-60. doi: 10.1007/s00787006-0508-9 
Bruce, H. A., \& Margolis, R. L. (2002). FOXP2: Novel exons, splice variants, and CAG repeat length stability. Human Genetics, 111(2), 136-144. doi: 10.1007/ s00439-002-0768-5

Brugada, R., Campuzano, O., Sarquella-Brugada, G., Brugada, P., Brugada, J., \& Hong, K. (2005). Brugada Syndrome. In Adam M. P., Ardinger H. H., Pagon R. A., et al., (Eds.). GeneReviews ${ }^{\circledR}$ [Internet]. Seattle (WA): University of Washington, Seattle; 1993-2019. Retrieved from https://www.ncbi.nlm.nih.gov/ pubmed/20301690

Cohen, N. J., Davine, M., Horodezky, N., Lipsett, L., \& Isaacson, L. (1993). Unsuspected language impairment in psychiatrically disturbed children: Prevalence and language and behavioral characteristics. Journal of the American Academy of Child \& Adolescent Psychiatry, 32(3), 595-603. doi: 10.1097/00004583-199305000-00016

Cope, N., Harold, D., Hill, G., Moskvina, V., Stevenson, J., Holmans, P., ... Williams, J. (2005). Strong evidence that KIAA0319 on chromosome $6 \mathrm{p}$ is a susceptibility gene for developmental dyslexia. The American Journal of Human Genetics, 76(4), 581-591. doi: 10.1086/429131

Chan, K. M., \& Fugard, A. J. (2018). Assessing speech, language and communication difficulties in children referred for ADHD: A qualitative evaluation of a UK child and adolescent mental health service. Clinical Child Psychology and Psychiatry, 23(3), 442-456. doi: 10.1177/1359104517753510

Eising, E., Carrion-Castillo, A., Vino, A., Strand, E. A., Jakielski, K. J., Scerri, T. S., ... Fisher, S. E. (2019). A set of regulatory genes co-expressed in embryonic human brain is implicated in disrupted speech development. Molecular Psychiatry, 24(7), 1065-1078. doi: 10.1038/s41380-018-0020-x

Enard, W., Przeworski, M., Fisher, S. E., Lai, C. S., Wiebe, V., Kitano, T., ... Pääbo, S. (2002). Molecular evolution of FOXP2, a gene involved in speech and language. Nature, 418(6900), 869-872. doi: 10.1038/nature01025

Estruch, S. B., Graham, S. A., Chinnappa, S. M., Deriziotis, P., \& Fisher, S. E. (2016). Functional characterization of rare FOXP2 variants in neurodevelopmental disorder. Journal of Neurodevelopmental Disorders, 8(1), 44. doi: 10.1186/ s11689-016-9177-2

Fenollar-Cortés, J., Gallego-Martínez, A., \& Fuentes, L. J. (2017). The role of inattention and hyperactivity/impulsivity in the fine motor coordination in children with ADHD. Research in Developmental Disabilities, 69, 77-84. doi: 10.1016/j.ridd.2017.08.003

Ferland, R. J., Cherry, T. J., Preware, P. O., Morrisey, E. E., \& Walsh, C. A. (2003). Characterization of Foxp2 and Foxp1 mRNA and protein in the developing and mature brain. Journal of Comparative Neurology, 460(2), 266-279. doi: 10.1002/cne. 10654

Feuk, L., Kalervo, A., Lipsanen-Nyman, M., Skaug, J., Nakabayashi, K., Finucane, B., ... Hannula-Jouppi, K. (2006). Absence of a paternally inherited FOXP2 gene in developmental verbal dyspraxia. The American Journal of Human Genetics, 79(5), 965-972. doi: 10.1086/508902

Fisher, S. E., \& Marcus, G. F. (2006). The eloquent ape: Genes, brains and the evolution of language. Nature Reviews Genetics, 7(1), 9-20. doi: 10.1038/nrg1747

Fisher, S. E., \& Scharff, C. (2009). FOXP2 as a molecular window into speech and language. Trends in Genetics, 25(4), 166-177. doi: 10.1016/j.tig.2009.03.002

FOXP2 protein [Homo sapiens] - Protein - NCBI. (n.d.). Retrieved from https://www. ncbi.nlm.nih.gov/protein/AAI43868.1

Friederici, A. D., \& Chomsky, N. (2017). The Functional Language Network. In Language in Our Brain. MIT Press Sholarship Online. doi: 10.7551/ mitpress/9780262036924.003.0005

Gao, R., Zaccard, C. R., Shapiro, L. P., Dionisio, L. E., Martin-de-Saavedra, M. D., Piguel, N. H., ... Penzes, P. (2019). The CNTNAP2-CASK complex modulates GluA1 subcellular distribution in interneurons. Neuroscience Letters, 701, 92 99. doi: 10.1016/j.neulet.2019.02.025

GeneCards $^{\circledR}$ : The Human Gene Database. (1997). Retrieved from https://www. genecards.org

Giddan, J. J., Milling, L., \& Campbell, N. B. (1996). Unrecognized language and speech deficits in preadolescent psychiatric inpatients. American Journal of Orthopsychiatry, 66(1), 85-92. doi: 10.1037/h0080158

Graham, S. A., \& Fisher, S. E. (2015). Understanding language from a genomic perspective. Annual Review of Genetics, 49(1), 131-160. doi: 10.1146/annurevgenet-120213-092236
Gregory S. G., Connelly J. J., Towers A. J., Johnson J., Biscocho D., Markunas C. A., ... Langford, C. F. (2009). Genomic and epigenetic evidence for oxytocin receptor deficiency in autism. BMC Medicine, 7(1), 62. doi: 10.1186/1741-7015-7-62

Hannenhalli, S., \& Kaestner, K. H. (2009). The evolution of Fox genes and their role in development and disease. Nature Reviews Genetics, 10(4), 233-240. doi: $10.1038 / \operatorname{nrg} 2523$

Hannula-Jouppi, K., Kaminen-Ahola, N., Taipale, M., Eklund, R., Nopola-Hemmi, J., Kääriäinen, H., \& Kere, J. (2005). The axon guidance receptor gene ROBO is a candidate gene for developmental dyslexia. PLoS Genetics, 1(4), 50. doi: 10.1371/journal.pgen.0010050

Holland, S. K., Plante, E., Byars, A. W., Strawsburg, R. H., Schmithorst, V. J., \& Ball Jr, W. S. (2001). Normal fMRI brain activation patterns in children performing a verb generation task. NeuroImage, 14(4), 837-843. doi: 10.1006/ nimg.2001.0875

Hoogman, M., Guadalupe, T., Zwiers, M. P., Klarenbeek, P., Francks, C., \& Fisher, S. E. (2014). Assessing the effects of common variation in the FOXP2 gene on human brain structure. Frontiers in Human Neuroscience, 8, 473. doi: 10.3389/ fnhum.2014.00473

Instituto Nacional de Estadística, Geografía e Informática, INEGI. (2000). XII Censo General de Población y Vivienda 2000. Retrieved from https://www.inegi.org. $\mathrm{mx} /$ programas/ccpv/2000/

Instituto Nacional de Estadística, Geografía e Informática, INEGI. (2004). Características de las personas con discapacidad del lenguaje. Retrieved from http://www.beta.inegi.org.mx/app/biblioteca/ficha.html?upc=702825010044

Iverson, J. M., \& Braddock, B. A. (2011). Gesture and motor skill in relation to language in children with language impairment. Journal of Speech, Language and Hearing Research, 54(1), 72-86. doi: 10.1044/1092-4388(2010/08-0197)

Ivorra, J. L., Rivero, O., Costas, J., Iniesta, R., Arrojo, M., Ramos-Ríos, R., ... Sanjuán, J. (2014). Replication of previous genome-wide association studies of psychiatric diseases in a large schizophrenia case-control sample from Spain. Schizophrenia Research, 159(1), 107-113. doi: 10.1016/j.schres.2014.07.004

Kelley, L. A., Mezulis, S., Yates, C. M., Wass, M. N., \& Sternberg, M. J. (2015). The Phyre2 web portal for protein modeling, prediction and analysis. Nature Protocols, 10(6), 845-858. doi: 10.1038/nprot.2015.053

Kemmerer, D., \& Gonzalez-Castillo, J. (2010). The two-level theory of verb meaning: An approach to integrating the semantics of action with the mirror neuron system. Brain and Language, 112(1), 54-76. doi: 10.1016/j. band1.2008.09.010

Khanzada, N., Butler, M., \& Manzardo, A. (2017). GeneAnalytics pathway analysis and genetic overlap among autism spectrum disorder, bipolar disorder and schizophrenia. International Journal of Molecular Sciences, 18(3), 527. doi: 10.3390/ijms 18030527

Kim, Y. S., \& State, M. W. (2014). Recent challenges to the psychiatric diagnostic nosology: A focus on the genetics and genomics of neurodevelopmental disorders. International Journal of Epidemiology, 43(2), 465-475. doi: 10.1093/ ije/dyu037

Konopka, G., Bomar, J. M., Winden, K., Coppola, G., Jonsson, Z. O., Gao, F., ... Geschwind, D. H. (2009). Human-specific transcriptional regulation of CNS development genes by FOXP2. Nature, 462(7270), 213-217. doi: 10.1038/ nature 08549

Krishnan, S., Watkins, K. E., \& Bishop, D. V. (2016). Neurobiological basis of language learning difficulties. Trends in Cognitive Sciences, 20(9), 701-714. doi: $10.1016 /$ j.tics.2016.06.012

Lai, C. S., Fisher, S. E., Hurst, J. A., Levy, E. R., Hodgson, S., Fox, M., ... Monaco, A. P. (2000). The SPCH1 region on human 7q31: genomic characterization of the critical interval and localization of translocations associated with speech and language disorder. The American Journal of Human Genetics, 67(2), 357-368. doi: $10.1086 / 303011$

Lai, C. S., Fisher, S. E., Hurst, J. A., Vargha-Khadem, F., \& Monaco, A. P. (2001). A forkhead-domain gene is mutated in a severe speech and language disorder. Nature, 413(6855), 519-523. doi: 10.1038/35097076

Lai, C. S., Gerrelli, D., Monaco, A. P., Fisher, S. E., \& Copp, A. J. (2003). FOXP2 expression during brain development coincides with adult sites of pathology in a severe speech and language disorder. Brain, 126(11), 2455-2462. doi: 10.1093/ brain/awg 247 
Li, S., Morley, M., Lu, M., Zhou, S., Stewart, K., French, C. A., ... Morrisey, E. E. (2016). Foxp transcription factors suppress a non-pulmonary gene expression program to permit proper lung development. Developmental Biology, 416(2), 338-346. doi: 10.1016/j.ydbio.2016.06.020

Li, S., Weidenfeld, J., \& Morrisey, E. E. (2004). Transcriptional and DNA binding activity of the Foxp1/2/4 family is modulated by heterotypic and homotypic protein interactions. Molecular and Cellular Biology, 24(2), 809-822. doi: 10.1128/mcb.24.2.809-822.2004

Lieberman, P. (2015). Chapter 36 Evolution of Language. In Muehlenbein, M. P. (Ed). Basics in Human Evolution, (pp. 493-503). doi: 10.1016/b978-0-12802652-6.00036-0

Liska, A., Bertero, A., Gomolka, R., Sabbioni, M., Galbusera, A., Barsotti, N., ... Gozzi, A. (2017). Homozygous loss of autism-risk gene CNTNAP2 results in reduced local and long-range prefrontal functional connectivity. Cerebral Cortex, 28(4), 1141-1153. doi: 10.1093/cercor/bhx022

Mattos, P., Rabelo, B., Gueiros, F., Soares, T., \& Coutinho, G. (2009). Specific language impairment in an adult with type I bipolar disorder: A case report. Revista Brasileira de Psiquiatria, 31(2), 191-192. doi: 10.1590/s151644462009000200023

Mccarthy, N. S., Clark, M. L., Jablensky, A., \& Badcock, J. C. (2019). No association between common genetic variation in FOXP2 and language impairment in schizophrenia. Psychiatry Research, 271, 590-597. doi: 10.1016/j. psychres.2018.12.016

McKusick, V.A. (1997, 27 octubre). OMIM Entry - \# 602081 - SPEECH-LANGUAGE DISORDER 1; SPCH1. Retrieved from https://omim.org/entry/602081

Meerschaut, I., Rochefort, D., Revençu, N., Pètre, J., Corsello, C., Rouleau, G. A., ... Callewaert, B. (2017). FOXP1-related intellectual disability syndrome: A recognisable entity. Journal of Medical Genetics, 54(9), 613-623. doi: 10.1136/ jmedgenet-2017-104579

Mendoza, E., \& Scharff, C. (2017). Protein-Protein interaction among the FoxP family members and their regulation of two target genes, VLDLR and CNTNAP2 in the Zebra Finch Song System. Frontiers in Molecular Neuroscience, 10, 112. doi: 10.3389/fnmol.2017.00112

Meng, H., Smith, S. D., Hager, K., Held, M., Liu, J., Olson, R. K., ... Gruen, J. R. (2005). DCDC2 is associated with reading disability and modulates neuronal development in the brain. Proceedings of the National Academy of Sciences, 102(47), 17053-17058. doi: 10.1073/pnas.0508591102

Mizutani, A., Matsuzaki, A., Momoi, M. Y., Fujita, E., Tanabe, Y., \& Momoi, T. (2007). Intracellular distribution of a speech/language disorder associated FOXP2 mutant. Biochemical and Biophysical Research Communications, 353(4), 869-874. doi: 10.1016/j.bbrc.2006.12.130

Moreno-Flagge, N. (2013). Trastornos del lenguaje. Diagnóstico y tratamiento. Revista de Neurología, 57(Supl 1), 85-94. doi: 10.33588/rn.57s01.2013248

Morgan, A., Fisher, S. E., Scheffer, I., \& Hildebrand, M. (2017). FOXP2-related speech and language disorders. In GeneReviews $\mathbb{R}$ [internet]. Seattle WA: University of Washington, Seattle. Retrieved from https://www.ncbi.nlm.nih. gov/pubmed/27336128

Morris, G., Stoychev, S., Naicker, P., Dirr, H. W., \& Fanucchi, S. (2018). The forkhead domain hinge-loop plays a pivotal role in DNA binding and transcriptional activity of FOXP2. Biological Chemistry, 399(8), 881-893. doi: 10.1515/hsz-2018-0185

National Center for Biotechnology Information. (s.f.). Online Mendelian Inheritance in Man (OMIM). Recuperado de https://www.ncbi.nlm.nih.gov/omim/

National Center for Biotechnology Information, U.S. National Library of Medicine. (s.f.). Gene. Retrieved from https://www.ncbi.nlm.nih.gov/gene

National Institutes of Health, The European Molecular Biology Laboratory, \& State Secretariat for Education, Research and Innovation SERI. (2002). Universal Protein Resource (UniProt). Retrieved from https://www.uniprot.org/

Newbury, D. F., Paracchini, S., Scerri, T. S., Winchester, L., Addis, L., Richardson, A. J., ... Monaco, A. P. (2011). Investigation of dyslexia and SLI risk variants in reading-and language-impaired subjects. Behavior Genetics, 41(1), 90-104. doi: 10.1007/s10519-010-9424-3

Newbury, D. F., Winchester, L., Addis, L., Paracchini, S., Buckingham, L., Clark, A., ... Monaco, A. P. (2009). CMIP and ATP2C2 modulate phonological short-term memory in language impairment. The American Journal of Human Genetics, 85(2), 264-272. doi: 10.1016/j.ajhg.2009.07.004
Nudel, R., \& Newbury, D. F. (2013). Foxp2. Wiley Interdisciplinary Reviews: Cognitive Science, 4(5), 547-560. doi: 10.1002/wcs.1247

Ocklenburg, S., Arning, L., Gerding, W. M., Epplen, J. T., Güntürkün, O., \& Beste, C. (2013). FOXP2 variation modulates functional hemispheric asymmetries for speech perception. Brain and Language, 126(3), 279-284. doi: 10.1016/j. bandl.2013.07.001

OMIM. (s.f.). Online Mendelian Inheritance in Man (OMIM). Retrieved from https:// www.ncbi.nlm.nih.gov/omim/

Oswald, F., Klöble, P., Ruland, A., Rosenkranz, D., Hinz, B., Butter, F., ... Herlyn, H. (2017). The FOXP2-Driven Network in Developmental Disorders and Neurodegeneration. Frontiers in Cellular Neuroscience, 11, 212. doi: 10.3389/ fncel.2017.00212

Peñagarikano, O., \& Geschwind, D. H. (2012). What does CNTNAP2 reveal about autism spectrum disorder?. Trends in Molecular Medicine, 18(3), 156-163. doi: 10.1016/j.molmed.2012.01.003

Peñagarikano, O., Lázaro, M. T., Lu, X., Gordon, A., Dong, H., Lam, H. A., ... Geschwind, D. H. (2015). Exogenous and evoked oxytocin restores social behavior in the Cntnap2 mouse model of autism. Science Translational Medicine, 7(271), 271ra8. doi: 10.1126/scitranslmed.3010257

Pettersen, E. F., Goddard, T. D., Huang, C. C., Couch, G. S., Greenblatt, D. M., Meng, E. C., \& Ferrin, T. E. (2004). UCSF Chimera-A visualization system for exploratory research and analysis. Journal of Computational Chemistry, 25(13), 1605-1612. doi: 10.1002/jcc.20084

Puglia, M. H., Lillard T. S., Morris J. P., \& Connelly J. J. (2015). Epigenetic modification of the oxytocin receptor gene influences the perception of anger and fear in the human brain. Proceedings of the National Academy of Sciences, 112(11), 3308-3313. doi: 10.1073/pnas.1422096112

Plump, A. S., Erskine, L., Sabatier, C., Brose, K., Epstein, C. J., Goodman, C. S., ... Tessier-Lavigne, M. (2002). Slit1 and Slit2 cooperate to prevent premature midline crossing of retinal axons in the mouse visual system. Neuron, 33(2), 219-232. doi: 10.1016/s0896-6273(01)00586-4

Radanovic, M., Nunes, P. V., Gattaz, W. F., \& Forlenza, O. V. (2008). Language impairment in euthymic, elderly patients with bipolar disorder but no dementia. International Psychogeriatrics, 20(4), 687-696. doi: 10.1017/ s1041610208007084

Raza, M. H., Domingues, C. E., Webster, R., Sainz, E., Paris, E., Rahn, R., ... Drayna, D. (2016). Mucolipidosis types II and III and non-syndromic stuttering are associated with different variants in the same genes. European Journal of Human Genetics, 24(4), 529-534. doi: 10.1038/ejhg.2015.154

Roll, P., Rudolf, G., Pereira, S., Royer, B., Scheffer, I. E., Massacrier, A., ... Szepetowski, P. (2006). SRPX2 mutations in disorders of language cortex and cognition. Human Molecular Genetics, 15(7), 1195-1207. doi: 10.1093/hmg/dd1035

Roll, P., Vernes, S. C., Bruneau, N., Cillario, J., Ponsole-Lenfant, M., Massacrier, A., ... Szepetowski, P. (2010). Molecular networks implicated in speech-related disorders: FOXP2 regulates the SRPX2/uPAR complex. Human Molecular Genetics, 19(24), 4848-4860. doi: 10.1093/hmg/ddq415

Royer-Zemmour, B., Ponsole-Lenfant, M., Gara, H., Roll, P., Lévêque, C., Massacrier, A., ... Szepetowski, P. (2008). Epileptic and developmental disorders of the speech cortex: Ligand/receptor interaction of wild-type and mutant SRPX2 with the plasminogen activator receptor uPAR. Human Molecular Genetics, 17(23), 3617-3630. doi: 10.1093/hmg/ddn256

Sanjuán, J., Tolosa, A., González, J. C., Aguilar, E. J., Pérez-Tur, J., Nájera, C., ... de Frutos, R. (2006). Association between FOXP2 polymorphisms and schizophrenia with auditory hallucinations. Psychiatric Genetics, 16(2), 67-72. doi: 10.1097/01.ypg.0000185029.35558.bb

Schomers, M. R., \& Pulvermüller, F. (2016). Is the sensorimotor cortex relevant for speech perception and understanding? An integrative review. Frontiers in Human Neuroscience, 10, 435. doi: 10.3389/fnhum.2016.00435

Sciberras, E., Mueller, K. L., Efron, D., Bisset, M., Anderson, V., Schilpzand, E. J., ... Nicholson, J. M. (2014). Language problems in children with ADHD: A community-based study. Pediatrics, 133(5), 793-800. doi: 10.1542/peds.2013-3355

Shu, W., Cho, J. Y., Jiang, Y., Zhang, M., Weisz, D., Elder, G. A., ... Buxbaum, J. D. (2005). Altered ultrasonic vocalization in mice with a disruption in the Foxp2 gene. Proceedings of the National Academy of Sciences, 102(27), 9643-9648. doi: 10.1073/pnas.0503739102 
Shu, W., Yang, H., Zhang, L., Lu, M. M., \& Morrisey, E. E. (2001). Characterization of a new subfamily of winged-helix/forkhead (Fox) genes that are expressed in the lung and act as transcriptional repressors. Journal of Biological Chemistry, 276(29), 27488-27497. doi: 10.1074/jbc.m100636200

Song, X., Tang, Y., \& Wang, Y. (2016). Genesis of the vertebrate FoxP subfamily member genes occurred during two ancestral whole genome duplication events. Gene, 588(2), 156-162. doi: 10.1016/j.gene.2016.05.019

Španiel, F., Horáček, J., Tintěra, J., Ibrahim, I., Novák, T., Čermák, J., ... Höschl, C. $(2011$,$) . Genetic variation in FOXP2 alters grey matter concentrations in$ schizophrenia patients. Neuroscience Letters, 493(3), 131-135. doi: 10.1016/j. neulet.2011.02.024

Spiteri, E., Konopka, G., Coppola, G., Bomar, J., Oldham, M., Ou, J., ... Geschwind, D. H. (2007). Identification of the transcriptional targets of FOXP2, a gene linked to speech and language, in developing human brain. The American Journal of Human Genetics, 81(6), 1144-1157. doi: 10.1086/522237

Stroud, J. C., Wu, Y., Bates, D. L., Han, A., Nowick, K., Paabo, S., ... Chen, L. (2006). Structure of the forkhead domain of FOXP2 bound to DNA. Structure, 14(1), 159-166. doi: 10.1016/j.str.2005.10.005

Sutcubasi Kaya, B., Metin, B., Tas, Z. C., Buyukaslan, A., Soysal, A., Hatiloglu, D., \& Tarhan, N. (2018). Gray matter increase in motor cortex in pediatric ADHD: A voxel-based morphometry study. Journal of Attention Disorders, 22(7), 611618. doi: 10.1177/1087054716659139

Teramitsu, I., Kudo, L. C., London, S. E., Geschwind, D. H., \& White, S. A. (2004). Parallel FoxP1 and FoxP2 expression in songbird and human brain predicts functional interaction. Journal of Neuroscience, 24(13), 3152-3163. doi: 10.1523/JNEUROSCI.5589-03.2004

Theofanopoulou, C. (2016). Implications of oxytocin in human linguistic cognition: from genome to phenome. Frontiers in Neuroscience, 10, 271. doi: 10.3389/ fnins.2016.00271

Thomas, A. C., Frost, J. M., Ishida, M., Vargha-Khadem, F., Moore, G. E., \& Stanier, P. (2012). The speech gene FOXP2 is not imprinted. Journal of Medical Genetics, 49(11), 669-670. doi: 10.1136/jmedgenet-2012-101242

Thordardottir, E. T., \& Weismer, S. E. (2002). Verb argument structure weakness in specific language impairment in relation to age and utterance length. Clinical Linguistics \& Phonetics, 16(4), 233-250. doi: 10.1080/02699200110116462

Toma, C., Pierce, K. D., Shaw, A. D., Heath, A., Mitchell, P. B., Schofield, P. R., \& Fullerton, J. M. (2018). Comprehensive cross-disorder analyses of CNTNAP2 suggest it is unlikely to be a primary risk gene for psychiatric disorders. PLOS Genetics, 14(12), e1007535. doi: 10.1371/journal.pgen.1007535

Trautman, R. C., Giddan, J. J., \& Jurs, S. G. (1990). Language risk factor in emotionally disturbed children within a school and day treatment program. Journal of Childhool Communication Disorders, 13(2), 123-133. doi: $10.1177 / 152574019001300201$

Trevisan, P., Sedeño, L., Birba, A., Ibáñez, A., \& García, A. M. (2017). A moving story: Whole-body motor training selectively improves the appraisal of action meanings in naturalistic narratives. Scientific Reports, 7(1), 12538. doi: 10.1038/s41598-017-12928-w

U.S. Department of Health \& Human Services. (s.f.). Genetics Home Reference. Retrieved from https://ghr.nlm.nih.gov/
Vargha-Khadem, F., Watkins, K., Alcock, K., Fletcher, P., \& Passingham, R. (1995). Praxic and nonverbal cognitive deficits in a large family with a genetically transmitted speech and language disorder. Proceedings of the National Academy of Sciences, 92(3), 930-933. doi: 10.1073/pnas.92.3.930

Vernes, S. C., Newbury, D. F., Abrahams, B. S., Winchester, L., Nicod, J., Groszer, M., ... Fisher, S. E. (2008). A functional genetic link between distinct developmental language disorders. New England Journal of Medicine, 359(22), 2337-2345. doi: 10.1056/NEJMoa0802828

Vernes, S. C., Nicod, J., Elahi, F. M., Coventry, J. A., Kenny, N., Coupe, A., ... Fisher, S. E. (2006). Functional genetic analysis of mutations implicated in a human speech and language disorder. Human Molecular Genetics, 15(21), 3154-3167. doi: $10.1093 / \mathrm{hmg} / \mathrm{ddl} 392$

Vernes, S. C., Spiteri, E., Nicod, J., Groszer, M., Taylor, J. M., Davies, K. E., ... Fisher, S. E. (2007). High-throughput analysis of promoter occupancy reveals direct neural targets of FOXP2, a gene mutated in speech and language disorders. The American Journal of Human Genetics, 81(6), 1232-1250. doi: 10.1086/522238

Wang, H. G., Jeffries, J. J., \& Wang, T. F. (2016). Genetic and developmental perspective of language abnormality in autism and schizophrenia: one disease occurring at different ages in humans?. The Neuroscientist, 22(2), 119-131. doi: $10.1177 / 1073858415572078$

Wang, R., Chen, C. C., Hara, E., Rivas, M. V., Roulhac, P. L., Howard, J. T., ... Jarvis, E. D. (2015). Convergent differential regulation of SLIT-ROBO axon guidance genes in the brains of vocal learners. Journal of Comparative Neurology, 523(6), 892-906. doi: 10.1002/cne.23719

Watkins, K. E., Vargha-Khadem, F., Ashburner, J., Passingham, R. E., Connelly, A., Friston, K. J., ... Gadian, D. G. (2002). MRI analysis of an inherited speech and language disorder: Structural brain abnormalities. Brain, 125(3), 465-478. doi: 10.1093/brain/awf057

Weigel, D., Jürgens, G., Küttner, F., Seifert, E., \& Jäckle, H. (1989). The homeotic gene fork head encodes a nuclear protein and is expressed in the terminal regions of the Drosophila embryo. Cell, 57(4), 645-658. doi: 10.1016/00928674(89)90133-5

Whitehouse, A. J., Bishop, D. V., Ang, Q. W., Pennell, C. E., \& Fisher, S. E. (2011). CNTNAP2 variants affect early language development in the general population. Genes, Brain and Behavior, 10(4), 451-456. doi: 10.1111/j.1601183X.2011.00684.X

Xu, S., Liu, P., Chen, Y., Chen, Y., Zhang, W., Zhao, H., ... Guo, X. (2018). Foxp2 regulates anatomical features that may be relevant for vocal behaviors and bipedal locomotion. Proceedings of the National Academy of Sciences, 115(35), 8799-8804. doi: 10.1073/pnas.1721820115

Yang, J. (2014). Influences of motor contexts on the semantic processing of actionrelated language. Cognitive, Affective, \& Behavioral Neuroscience, 14(3), 912922. doi: 10.3758/s13415-014-0258-y

Zhou, W., Zhang, J., Li, Z., Lin, X., Li, J., Wang, S., ... Wei, L. (2019). Targeted resequencing of 358 candidate genes for autism spectrum disorder in a Chinese cohort reveals diagnostic potential and genotype-phenotype correlations. Human Mutation, 40(6), 801-815. doi: 10.1002/humu.23724 